Fernandez-Duque, F., R. L. Bailey, and D. N. Bonter. 2019. Egg oiling as an effective management technique for limiting reproduction in an invasive passerine. Avian Conservation and Ecology 14(2):20. https://doi.org/10.5751/ACE-01491-140220

Copyright $(C) 2019$ by the author(s). Published here under license by the Resilience Alliance.

Research Paper

\title{
Egg oiling as an effective management technique for limiting reproduction in an invasive passerine
}

\author{
Facundo Fernandez-Duque ${ }^{1}$, Robyn L. Bailey ${ }^{1}$ and David N. Bonter ${ }^{1}$ \\ ${ }^{1}$ Cornell Lab of Ornithology
}

\begin{abstract}
The House Sparrow (Passer domesticus), native to Europe and Asia, has been introduced globally and is now one of the most ubiquitous birds in the world. In North America, these invasive passerines compete with native species for nest cavities, which are often limited. Because of the difficulties of extirpating an invasive species and the growing desire from the public to help in conservation matters, we sought to test a potential technique for managing invasive cavity-nesting passerines that could be successfully deployed by professionals and citizen scientists alike. Previous studies demonstrate that applying vegetable oil to eggs is a nontoxic management technique often used to manage unwanted waterfowl. Further, egg oiling is a technique that is acceptable to a large segment of the public. This study assesses the efficacy of applying vegetable oil for preventing House Sparrow eggs from hatching, reducing the number of fledged young, prolonging incubation time, and delaying renesting attempts by the adults. We sprayed treatment clutches once with approximately $0.8 \mathrm{ml}$ of vegetable oil early in the developmental period and subsequently monitored nests every 3-4 days. The application of vegetable oil to treated eggs was $100 \%$ effective at preventing hatching and, thus, preventing any offspring from fledging. Furthermore, the adults in the treatment group incubated their eggs for nearly twice as long as the adults at control nests, reducing their opportunity to produce more clutches later in the season. Given the availability, low cost, and effectiveness of applying vegetable oil to eggs to prevent the reproductive output of invasive cavity-nesting passerines, we propose that this method can be easily implemented by wildlife managers as well as trained nest box stewards.
\end{abstract}

\section{L'huilage des oeufs en tant que technique de gestion efficace pour limiter la reproduction d'un passereau invasif}

RÉSUMÉ. Le moineau domestique (Passer domesticus), originaire d'Europe et d'Asie, a été introduit dans le monde entier et est aujourd'hui l'un des oiseaux les plus répandus sur la planète. En Amérique du Nord, ces passereaux invasifs concurrencent les espèces natives dans la recherche de cavités où installer leur nid, lesquelles sont souvent limitées. Compte tenu des difficultés que représente l'extirpation d'une espèce invasive et du désir croissant du public de participer aux efforts de conservation, nous avons tenté de tester une technique qui pourrait permettre de gérer les passereaux invasifs nichant dans des cavités. Cette solution pourrait être mise en place avec succès par des professionnels comme par le grand public intéressé par la science. Des études antérieures démontrent que l'application d'huile végétale sur les oeufs est une technique de gestion non-toxique souvent utilisée pour gérer les oiseaux aquatiques indésirables. En outre, l'huilage des oeufs est une technique acceptable pour une grande partie du public. Cette étude évalue l'efficacité de l'application d'huile végétale pour empêcher les oeufs des moineaux domestiques d'éclore, réduisant ainsi le nombre d'oisillons, prolongeant la durée d'incubation et retardant les tentatives de renidification des adultes. Nous avons testé la vaporisation d'oeufs avec environ $0,8 \mathrm{ml}$ d'huile végétale au début de la période de développement et par la suite surveillé les nids tous les 3 à 4 jours. L'application d'huile végétale sur les oeufs traités s'est avérée efficace à $100 \%$ pour empêcher l'éclosion et par conséquent, éviter l'envol des oisillons. En outre, les adultes du groupe de traitement couvaient leurs oeufs près de deux fois plus longtemps que les adultes des groupes de contrôle, ce qui réduisait leurs opportunités de produire d'autres couvées plus tard dans la saison. Compte tenu de la disponibilité, du coût réduit et de l'efficacité de l'application d'huile végétale sur les oeufs pour empêcher la reproduction de passereaux invasifs nichant dans des cavités, nous considérons que cette méthode pourrait être mise en oeuvre facilement par les gestionnaires de la faune sauvage comme par des observateurs de nids formés.

Key Words: birds; cavity-nesting; egg oiling; extirpating; House Sparrow; invasive passerines; management

\section{INTRODUCTION}

Invasive species are among the major factors threatening global biodiversity (Clavero et al. 2009, IUCN 2010, Szabo et al. 2012, Baker et al. 2014). Avian communities are particularly susceptible to external disturbances, with invasive species being responsible for $58.2 \%$ of known bird extinctions since 1500 (Szabo et al. 2012). Increasingly, research demonstrates that introduced mammals including rodents, e.g., rats and mice (Thibault et al. 2002,
Nentwig et al. 2010, Ratcliffe et al. 2009), mustelids (Ferreras and Macdonald 1999, Moller and Alterio 1999, Dowding and Murphy 2001, Dilks et al. 2003, Kelly et al. 2005), and feral cats (Bonnaud et al. 2007, Balogh et al. 2011, Loss et al. 2013, 2015, Woinarski et al. 2017) pose a major threat to some bird populations.

The impacts of introduced birds on populations of native birds, however, receive relatively little research attention when compared 
to mammals. Some studies demonstrate that birds can be as harmful as the most damaging mammal species (Kumschick and Nentwig 2010). A recent review showed that non-native birds impact avian populations through predation, brood parasitism, hybridization, competition for resources, and disease transmission (Baker et al. 2014). Among cavity-nesting species, competition between native and non-native birds for nesting sites can be intense (Fisher and Wiebe 2006, Aitken and Martin 2008, Frei et al. 2015, Charter et al. 2016). In Europe, experimental evidence suggests that the Ring-necked Parakeet (Psittacula krameri) is contributing to the decline in Eurasian Nuthatch (Sitta europaea) populations because of competition over nest sites (Strubbe and Matthysen 2007, 2009). Likewise, House Sparrows (Passer domesticus), one of the most globally ubiquitous invasive birds, usurp nest sites and negatively impact the reproductive success of native birds throughout their introduced range (Gowaty 1984, Radunzel et al. 1997, Ghilain and Bélisle 2008, Goldshtein et al. 2018).

Unfortunately, management approaches for limiting nest site competition between invasive and native species are limited (Bomford and Sinclair 2002, Grarock et al. 2013, 2014, Orchan et al. 2013, Charter et al. 2016). The most common management technique has been to trap and euthanize invasive species (Fitzwater 1988, Soh et al. 2002, Tracey et al. 2008). In the southeastern United States, the trap and euthanize approach has minimized the disruptive behavior of the Monk Parakeet (Myiopsitta monachus), which tend to nest on utility infrastructure (Tillman et al. 2004). Such approaches can create ethical conflicts, however, and widespread use of this approach among the public is unlikely. The use of toxic chemicals is another technique used to control invasive birds, e.g., European Starling (Sturnus vulgaris; Decino et al. 1966, Besser et al. 1967, West 1968, Linz et al. 2007, Carlson et al. 2011). Chemical treatments, however, are not species-specific and the potential effects of such treatments on nontarget taxa must be considered (Cunningham et al. 1979, Cummings et al. 2002, Eisemann et al. 2003). Even when relying on species-specific methods of management, these can still have unforeseen negative consequences on native species because of complex interactions among species in cavity-nesting bird communities (Orchan et al. 2013).

Eradicating or limiting population growth of invasive species without negatively affecting native species is extremely difficult; there continues to be a need for new management techniques and approaches. Because many birds nest on private land, approaches that engage the public in limiting the reproductive success of invasive birds deserve attention. One potential technique, regularly used with nonpasserines such as waterfowl and gulls, involves applying mineral or vegetable oil to the clutch of eggs in a nest. Coating an egg in oil inhibits oxygen diffusion through eggshell pores, thereby terminating development (Martin et al. 2007). The application of oil to eggs is effective at limiting reproduction, preventing $90-100 \%$ of oiled eggs from hatching (Thomas 1972, Blokpoel and Hamilton 1989, Christens et al. 1995, Pochop et al. 1998a, b, Martin et al. 2007, Hindman et al. 2014). In contrast to direct nest removal, this technique prevents the eggs from developing while continuing to keep the parents actively engaged in incubation behavior rather than investing in a renesting attempt (Thomas 1972, Christens et al. 1995, Pochop et al. 1998a, Hindman et al. 2014, Beaumont et al. 2018). This management strategy has been focused primarily on species that nest in colonies because of the ease of targeting numerous nests at once (Pochop et al. 1998b, Blackwell et al. 2000, Martin et al. 2007, Devault et al. 2014).

Coating eggs in oil can also be used for cavity-nesting species. In the last century, the establishment and care of nest boxes across the United States and Canada has increased in popularity, a byproduct of the rise in recreational birdwatching (Lepczyk et al. 2004, U.S. Department of the Interior et al. 2013, Federal, Provincial, and Territorial Governments of Canada 2014, Raleigh et al. 2019). This has led to a substantial community of people that enjoys native nesting birds and is therefore interested in deterring invasive species using their nest boxes, e.g., House Sparrows and European Starlings. In North America, many people who monitor nest boxes confront the invasive species problem by removing House Sparrow nests from their nest boxes (Kibler 1969, Scriven 1993, Larson et al. 2016). In this case, nest removal is allowable under the Migratory Bird Treaty Act of 1918 in the U.S. and the Migratory Birds Convention Act of 1994 of Canada, which only protect native species. Although this approach effectively terminates the nesting attempt, an evicted pair can still take over a nearby nest cavity to renest, potentially disrupting the nesting efforts of native species. Thus, removing the nest of the invasive species may be counterproductive if it leads the invasive species to usurp a nearby nest site.

In our study, we tested the feasibility and effectiveness of egg oiling as an approach to reducing the reproductive success of House Sparrows while minimizing the impact on native species. Although effective at limiting reproduction in other taxa, the egg oiling technique has rarely been applied to passerines. We hypothesized that a single application of vegetable oil to House Sparrow eggs would limit their reproductive success while minimizing disturbance to the pair such that incubation of nonviable eggs would continue. Specifically, we predicted that the application of vegetable oil to eggs would prolong the amount of time adults spent incubating, reduce hatching success, and reduce the number of young that fledged per nesting attempt compared to control (untreated) nests.

\section{MATERIALS AND METHODS}

\section{Field sites and methods}

We conducted our study in the towns of Ithaca and Lansing in Tompkins County, New York, USA $\left(\sim 42^{\circ} 34^{\prime} \mathrm{N}, 76^{\circ} 33^{\prime} \mathrm{W}\right)$. Nest boxes $(n=80)$ were installed and monitored for signs of House Sparrow activity every three to four days throughout the breeding season (April-August 2018). All boxes were designed for Tree Swallows (Tachycineta bicolor) and Eastern Bluebirds (Sialia sialis) and had a $3.8 \mathrm{~cm}$ diameter entrance hole following the Cornell Lab of Ornithology's recommendations for Eastern Bluebird box design (Cornell Lab of Ornithology 2019). These boxes are regularly used by House Sparrows. When a House Sparrow clutch was completed, the nest was assigned to either the treatment (oiling) or control group (no oiling). At each site, every fourth completed nest was assigned to the control group and the nesting attempt was allowed to proceed with only minimal disturbance for monitoring purposes. We monitored 51 House Sparrow nest attempts between April and August 2018 (44 treatment and seven control). 
Treated eggs were gently removed from the nest, placed on the grass at the foot of the nest box, and sprayed once with foodgrade sprayable vegetable oil, i.e., canola cooking oil spray. We applied $\sim 0.8 \mathrm{ml}$ of canola oil, i.e., a spray of approximately two seconds in duration, to treated eggs. The eggs were then returned to the nest, with the entire process taking less than two minutes. The control eggs did not receive a parallel treatment because we sought to test for differences in hatching success between treated eggs and unmanipulated nests. After treatment, nests were monitored every three to four days for signs of continued incubation defined by parental activity at the box, or in the absence of adults, by briefly placing fingers on the eggs to test for warmth. At each visit, we classified a nesting attempt as failed (cold eggs, no adult flushing from the box, lack of adults in the vicinity, etc.) or ongoing.

Many House Sparrow pairs initiated another clutch in the same box while the box still contained eggs from the previous clutch. When this happened, we considered the new clutch as a new nesting attempt and only the new eggs were counted for the clutch size calculations. After clutches were completed in renesting attempts, all eggs in boxes in the treatment group were sprayed following the aforementioned protocol. Because $90 \%$ of individually marked females $(n=20)$ chose to renest in the same box after the first clutch failed to hatch, we assumed that pair identity remained the same for subsequent attempts in the nest boxes attended by unbanded birds. Treatment (oil or control) was assigned to the box and maintained for all nesting attempts throughout the breeding season.

\section{Statistical methods}

To test for treatment-based difference in the length of incubation, we constructed a mixed model where the number of days that the eggs were incubated was modeled as a function of treatment (categorical: control vs. oiled) and attempt within the nesting season (categorical: 1, 2, 3, or 4, PROC GLIMMIX in SAS, log link, Poisson distribution, SAS Institute 2012). Because individual pairs attempted up to four nests within a season, pair identity was included as a repeated variable in the model. We report raw means and standard errors in the figure to aid in interpretation.

To investigate the effectiveness of egg oiling as a strategy for preoccupying birds with nonviable eggs, we created a second mixed model (PROC GLIMMIX, Poisson distribution) with the days between initiation of sequential clutches (interclutch interval) within pairs as the response variable. Interclutch interval was modeled as a function of treatment (oiled or control), with pair identifier as the random variable.

\section{RESULTS}

The mean length of incubation in treated nests was almost twice as long as the incubation time in control nests $\left(F_{1,19}=2.36, P=\right.$ 0.029; Fig. 1). Oiled nests were incubated for as few as 6 days and as long as 44 days before the clutch was either abandoned or renesting was initiated. The length of the incubation period did not vary seasonally with nesting attempt number $\left(F_{3,19}=0.01, P\right.$ $=0.998)$.

Birds nesting in control nest boxes were more likely to fledge offspring than birds using boxes receiving the oil treatment (Fig.
2; range 1-5 fledglings per successful nesting attempt in control nests). No eggs hatched, and therefore no chicks fledged, from treated nests.

Fig. 1. Mean incubation length (days \pm standard error) for House Sparrows (Passer domesticus) in control nests and nests where eggs were sprayed with vegetable oil to prevent hatching ( $n=7$ and 44 nests, respectively).

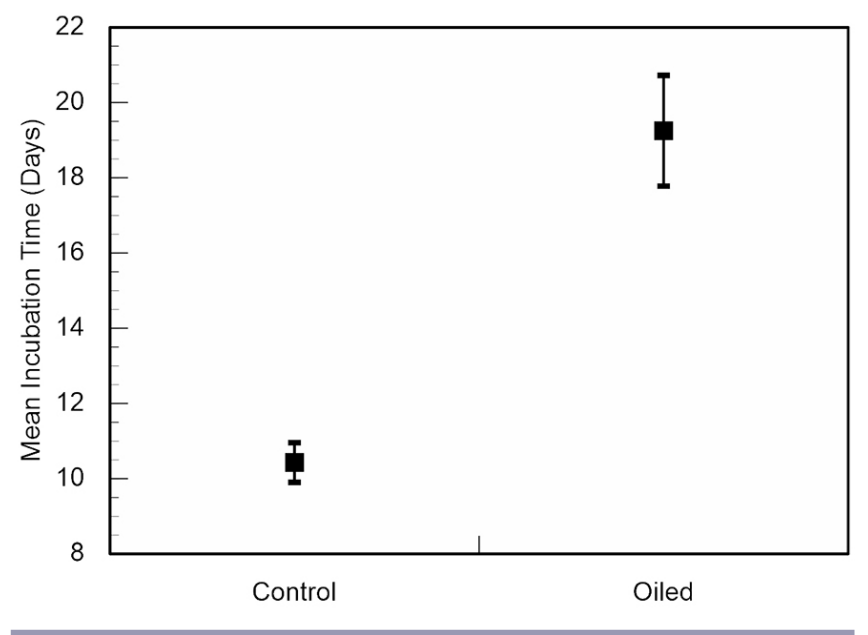

Fig. 2. Mean number of offspring fledged per nesting attempt ( \pm standard error) by House Sparrows (Passer domesticus) in control nests and nests where eggs were sprayed with vegetable oil to prevent hatching.

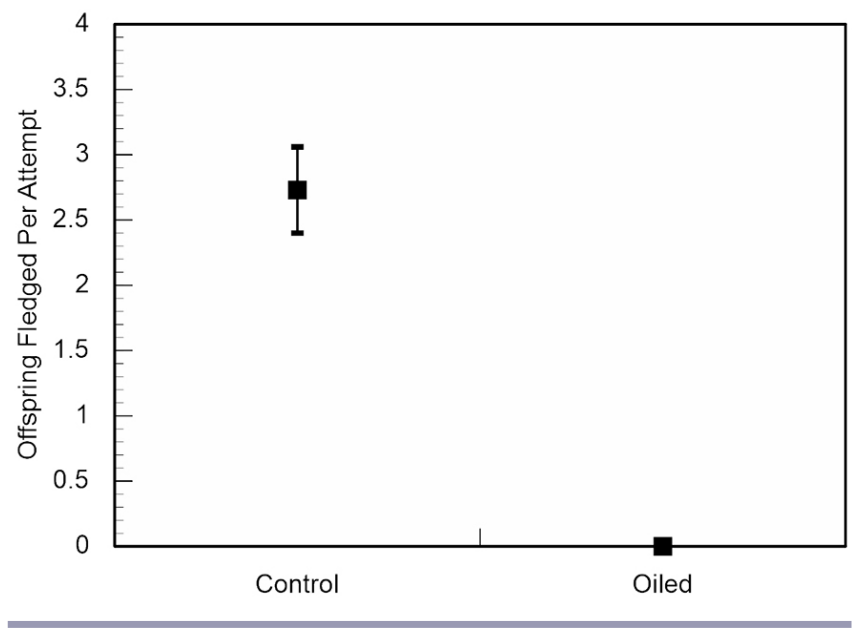

Although the birds in control nests hatched, fed, and fledged offspring, birds with oiled clutches delayed renesting for extended periods of time with renesting intervals that were only 8 days shorter, on average, than control nests $\left(F_{1,4}=1.53, P=0.200\right.$, Fig. $3)$. Pairs in the treatment group sometimes laid new eggs in the nest with the existing, unhatched eggs $(n=12)$, with the maximum clutch size reaching 11 total new and previously treated eggs. Frequently, pairs removed some eggs before laying a new clutch (43\% of renesting attempts). 
Fig. 3. Mean number of days ( \pm standard error) between nesting attempts by House Sparrows (Passer domesticus) in control nests and nests where eggs were sprayed with vegetable oil to prevent hatching.

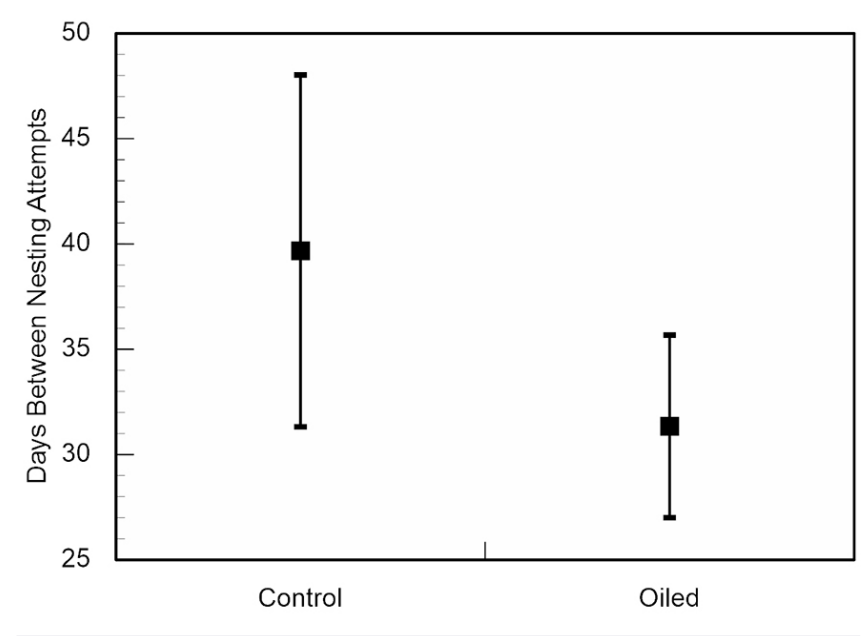

\section{DISCUSSION}

We found that the single application of sprayable canola oil to House Sparrow eggs prolonged incubation time and reduced reproductive success to zero. The effectiveness of the oiling treatment in preventing hatching and extending incubation time corroborates the findings of other studies utilizing oils on nonpasserine eggs (Pochop et al. 1998a, Devault et al. 2014, Hindman et al. 2014). Further, we found that House Sparrow pairs at treated nests tended to renest in the same nest box. Because removing the nests of the invasive species often leads birds to seek other nesting sites, nest removal may actually be counterproductive as native species may be evicted from nearby nest boxes (Berger et al. 2001). The egg oiling approach, therefore, was completely effective at eliminating reproduction by House Sparrows while limiting usurpation of occupied nest sites. Because birds at treated nests tended to initiate a renesting attempt within a month of the initial application of oil, nest box stewards must remain vigilant and spray new clutches as they appear throughout the breeding season to effectively limit reproduction.

Worldwide, several of the most successful invasive bird species are cavity-nesters (Lowe et al. 2000). This reliance on cavities for nest sites places invasive birds in direct competition with native species over a potentially limiting resource (Strubbe and Matthysen 2009, Charter et al. 2016). Invasive species may usurp nest sites from native species via physical competition or by initiating nesting earlier in the season, thereby pre-emptively occupying optimal nest sites. Although numerous studies report negative impacts of invasive cavity-nesting birds on native avifauna, few studies suggest successful, feasible management strategies (Stone and Loope 1987, Manchester and Bullock 2000, Avery and Tillman 2005, Avery et al. 2008, Khan et al. 2011, Ahmad et al. 2012).

As with nest removal, other strategies for managing invasive cavity-nesting birds have drawbacks. Trapping and euthanizing adults is likely to have the most rapid and significant effect on decreasing local populations (Weitzel 1988); however, trapping adults requires considerable effort. Further, euthanizing trapped birds raises ethical concerns and may not be feasible in public access settings. In a survey of citizen scientists who monitor nest boxes, euthanizing and shooting non-native species were less popular management techniques than removing nests or eggs (Larson et al. 2016).

Methods of addling eggs beyond the application of oil may include piercing or shaking, processes that are generally considered humane if performed during the earliest stages of embryonic development (Humane Society of the United States 2009). These techniques are typically deployed on eggs of waterfowl and larger species, however. Shaking or piercing the small, relatively fragile eggs of passerines may result in egg breakage. Damaging eggs by such techniques would effectively result in nest removal, with the associated risk of focal birds moving to nearby nest boxes. Recently, researchers have begun testing the efficacy of swapping the eggs of House Sparrows with wooden replicas to keep the adults occupied during the breeding season (Sparrow Swap 2019). Although this may have a similar result to the egg-oiling conducted in our study, replica eggs must be of similar size and coloration or they will be ejected from the nest. Such egg replicas are not readily available to the public, and large numbers of replicas would be required for people attempting to manage multiple House Sparrow nests in large colonies. On the other hand, sprayable vegetable oil is inexpensive, readily available, and is generally acceptable to the public (Pochop et al. $1998 b$ ). Egg-oiling likely limits damage to neighboring birds' nests, does not require nest box modifications, and could be conducted in areas where trapping and euthanizing were not desirable, e.g., public parks.

Although addling House Sparrow eggs via the application of oil shows positive results for managing invasive species that nest in cavities, more research is needed to understand the long-term effects of this management strategy. Although egg-oiling was extremely effective in reducing the reproductive output of treated birds in our study, we cannot determine if this reduction would eventually lead to population-level declines or if immigration would compensate for the reduction in local reproductive success. For instance, a study of Double-crested Cormorant (Phalacrocorax auritus) colonies showed that egg-oiling increased movement to unmanaged colonies by $20 \%$, a strategy that House Sparrows could adopt to circumvent management strategies (Duerr et al. 2007). House Sparrows are highly sedentary birds, however, with breeding season home ranges of 1-2 km (Dyer et al. 1977), so it is possible that property owners could reduce the local population via consistent efforts at oiling eggs. Our study also has potential implications for other invasive passerines that may compete for larger nest boxes, such as European Starlings. More studies are required to determine if egg-oiling alone can meaningfully reduce invasive species populations and subsequently increase reproductive success by native species.

National citizen-science nest monitoring projects (e.g., https:// nestwatch.org/) may allow researchers to test these hypotheses on a larger scale with the help of an engaged community of nest box stewards (Phillips and Dickinson 2009). As previously mentioned, permits are not required for citizen scientists to manage non- 
native birds in nest boxes; indeed, many nest box trail managers already do (Larson et al. 2016). Whereas professional wildlife managers may need to balance competing priorities and triage the most urgent threats, they could train citizen scientists to implement the relatively straightforward, nontoxic egg-oiling tasks, thereby increasing opportunities for volunteer stewardship on public lands. In fact, many agencies already enlist volunteer labor to manage invasive plants, snakes, and other taxa (Perry et al. 2019). Because House Sparrows are among the most steeply declining of all North American bird species (Rosenberg et al. 2019), some may argue that hastening their decline is unwarranted; however, Perry et al. (2019) argue that failure to act in controlling invasive species constitutes negligence and that citizen scientists are promising allies for biodiversity conservation. Consider the Purple Martin (Progne subis), Tree Swallow, and Violet-green Swallow (Tachycineta thalassina), which are cavity-nesting members of the aerial insectivore guild that is in acute decline throughout North America (Nebel et al. 2010, Rosenberg et al. 2019); these species may present a good case for when to prioritize the management of House Sparrows in nest boxes. Further, this study demonstrates that egg-oiling is an effective way to limit reproduction in an invasive passerine, which may prove useful as a tool for managing future invasions by other species.

\section{CONCLUSION}

We found that a modest application of vegetable oil to a clutch of House Sparrow eggs completely prevented hatching, thus effectively suppressing reproduction. Although the egg-oiling technique is frequently used to manage larger species such as waterfowl, it was previously unknown whether small cavitynesting passerines would incubate oiled eggs. Because of the cavity-nesting habits and smaller body sizes of many invasive passerines, e.g., House Sparrow, European Starling, Common Myna (Acridotheres tristis), this management technique could be a viable way to limit reproduction by non-native species without damaging native species. Furthermore, citizen scientists interested in helping native species that use their nest boxes would be able to participate in management efforts without increasing risk to nearby native birds in nest boxes (compared to removing nests and eggs). Although the results of egg oiling are promising and the technique could potentially be implemented on a large scale, further studies are required to understand population-level impacts of egg oiling on invasive species.

\section{Responses to this article can be read online at:}

http://www.ace-eco.org/issues/responses.php/1491

\section{Acknowledgments:}

This research was supported by the Cornell Lab of Ornithology and an Undergraduate Engaged Research Program grant from the Office of Engagement Initiatives at Cornell University. Cornell University's Institutional Animal Care and Use Committee approved the procedures for the study under Protocol \# 2008-0083. We thank numerous landowners for allowing us to perform this study on their property. We thank all of the Avian Conservation and Ecology manuscript reviewers for providing insightful comments and revisions. We also thank Rachael Mady for helping develop the study and collecting data.

\section{LITERATURE CITED}

Ahmad, S., H. A. Khan, M. Javed, and Khalil-Ur-Rehman. 2012. Management of maize and sunflower against the depredations of Rose-ringed Parakeet (Psittacula krameri) using mechanical repellents in an agro-ecosystem. International Journal of Agriculture and Biology 14:286-290.

Aitken, K. E. H., and K. Martin. 2008. Resource selection plasticity and community responses to experimental reduction of a critical resource. Ecology 89:971-980. https://doi.org/10.1890/07-0711.1

Avery, M. L., and E. A. Tillman. 2005. Alien birds in North America-challenges for wildlife managers. Pages 82-89 in D. L. Nolte and K. A. Fagerstone, editors. Wildlife damage management conference - Proceedings. Wildlife Damage Management, Internet Center.

Avery, M. L., C. A. Yoder, and E. A. Tillman. 2008. Diazacon inhibits reproduction in invasive Monk Parakeet populations. Journal of Wildlife Management 72:1449-1452. https://doi. org/10.2193/2007-391

Baker, J., K. J. Harvey, and K. French. 2014. Threats from introduced birds to native birds. Emu - Austral Ornithology 114:1-12. https://doi.org/10.1071/MU12122

Balogh, A. L., T. B. Ryder, and P. P. Marra. 2011. Population demography of Gray Catbirds in the suburban matrix: sources, sinks and domestic cats. Journal of Ornithology 152:717-726. https://doi.org/10.1007/s10336-011-0648-7

Beaumont, M., J. Rodrigue, C. Pilotte, E. Chalifour, and J.-F. Giroux. 2018. Behavioral response of Canada Geese to egg-oiling and nest removal. Journal of Wildlife Management 82:1359-1366. https://doi.org/10.1002/jwmg.21486

Berger, C., K. Kridler, and J. Griggs. 2001. The bluebird monitor's guide to bluebirds and other small cavity-nesters. Collins Reference, New York, New York, USA.

Besser, J. F., W. C. Royall Jr, and J. W. Degrazio. 1967. Baiting starlings with DRC-1339 at a cattle feedlot. Journal of Wildlife Management 31:48-51. https://doi.org/10.2307/3798359

Blackwell, B. F., T. W. Seamans, D. A. Helon, and R. A. Dolbeer. 2000. Early loss of Herring Gull clutches after egg-oiling. Wildlife Society Bulletin 28:70-75.

Blokpoel, H., and R. M. G. Hamilton. 1989. Effects of applying white mineral oil to chicken and gull eggs. Wildlife Society Bulletin $17: 435-441$.

Bomford, M., and R. Sinclair. 2002. Australian research on bird pests: impact, management and future directions. Emu - Austral Ornithology 102:29-45. https://doi.org/10.1071/MU01028

Bonnaud, E., K. Bourgeois, E. Vidal, Y. Kayser, Y. Tranchant, and J. Legrand. 2007. Feeding ecology of a feral cat population on a small Mediterranean island. Journal of Mammalogy 88:1074-1081. https://doi.org/10.1644/06-MAMM-A-031R2.1

Carlson, J. C., R. M. Engeman, D. R. Hyatt, R. L. Gilliland, T. J. DeLiberto, L. Clark, M. J. Bodenchuk, and G. M. Linz. 2011. 
Efficacy of European Starling control to reduce Salmonella enterica contamination in a concentrated animal feeding operation in the Texas panhandle. BMC Veterinary Research 7:1-10. https://doi.org/10.1186/1746-6148-7-9

Charter, M., I. Izhaki, Y. Ben Mocha, and S. Kark. 2016. Nestsite competition between invasive and native cavity nesting birds and its implication for conservation. Journal of Environmental Management 181:129-134. https://doi.org/10.1016/j.jenvman.2016.06.021

Christens, E., H. Blokpoel, G. Rason, and S. W. D. Jarvie. 1995. Spraying white mineral oil on Canada Goose eggs to prevent hatching. Wildlife Society Bulletin 23:228-230.

Clavero, M., L. Brotons, P. Pons, and D. Sol. 2009. Prominent role of invasive species in avian biodiversity loss. Biological Conservation 142:2043-2049. https://doi.org/10.1016/j.biocon.2009.03.034

Cornell Lab of Ornithology. 2019. NestWatch: Eastern Bluebird nest box plan and information. Cornell Lab of Ornithology, Ithaca, New York, USA. [online] URL: https://nestwatch.org/learn/allabout-birdhouses/birds/eastern-bluebird/

Cummings, J. L., J. F. Glahn, E. A. Wilson, and J. E. Davis Jr. 2002. Potential hazards of DRC-1339 treated rice to non-target birds when used at roost staging areas in Louisiana to reduce local populations of depredating blackbirds. International Biodeterioration \& Biodegradation 49:185-188. https://doi.org/10.1016/s0964-8305 (01)00121-4

Cunningham, D. J., E. W. J. Schafer, and L. K. McConnell. 1979. DRC-1339 and DRC-2698 residues in starlings: preliminary evaluation of their effects on secondary hazard potential. Pages 31-37 in W. B. Jackson, editor. Bird control seminars proceedings. Wildlife Damage Management, Internet Center.

Decino, T. J., D. J. Cunningham, and E. W. Schafer. 1966. Toxicity of DRC-1339 to starlings. Journal of Wildlife Management 30:249-253. https://doi.org/10.2307/3797809

Devault, T. L., P. M. Schmidt, F. E. Pogmore, J. Gobeille, and J. L. Belant. 2014. Influence of egg oiling on colony presence of ring-billed gulls. Human-Wildlife Interactions 8:22-30.

Dilks, P., M. Willans, M. Pryde, and I. Fraser. 2003. Large scale stoat control to protect Mohua (Mohoua ochrocephala) and Kaka (Nestor meridionalis) in the Eglinton Valley, Fiordland, New Zealand. New Zealand Journal of Ecology 27:1-9.

Dowding, J. E., and E. C. Murphy. 2001. The impact of predation by introduced mammals on endemic shorebirds in New Zealand: a conservation perspective. Biological Conservation 99:47-64. https://doi.org/10.1016/S0006-3207(00)00187-7

Duerr, A. E., T. M. Donovan, and D. E. Capen. 2007. Management-induced reproductive failure and breeding dispersal in Double-crested Cormorants on Lake Champlain. Journal of Wildlife Management 71:2565-2574. https://doi.org/10.2193/2006-527

Dyer, M. I., J. Pinowski, and B. Pinowska. 1977. Population dynamics. Pages 53-105 in J. Pinowski and S. C. Kendeigh, editors. Granivorous birds in ecosystems. Cambridge University Press, Cambridge, UK.

Eisemann, J. D., P. A. Pipas, and J. L. Cummings. 2003. Acute and chronic toxicity of compound DRC-1339 (3-chloro-4- methylaniline hydrochloride) to birds. USDA National Wildlife Research Center - Staff Publications 49-56.

Federal, Provincial, and Territorial Governments of Canada. 2014. 2012 Canadian nature survey: awareness, participation, and expenditures in nature-based recreation, conservation, and subsistence activities. Canadian Councils of Resource Ministers, Ottawa, Ontario, Canada.

Ferreras, P., and D. W. Macdonald. 1999. The impact of American mink Mustela vison on water birds in the upper Thames. Journal of Applied Ecology 36:701-708. https://doi.org/10.1046/ j.1365-2664.1999.00431.x

Fisher, R. J., and K. L. Wiebe. 2006. Nest site attributes and temporal patterns of Northern Flicker nest loss: effects of predation and competition. Oecologia 147:744-753. https://doi. org/10.1007/s00442-005-0310-2

Fitzwater, W. D. 1988. Solutions to urban bird problems. Pages 254-259 in A. C. Crabb and R. E. Marsh, editors. Proceedings of the Thirteenth Vertebrate Pest Conference. Monterey, California, USA.

Frei, B., J. J. Nocera, and J. W. Fyles. 2015. Interspecific competition and nest survival of the threatened Red-headed Woodpecker. Journal of Ornithology 156:743-753. https://doi. org/10.1007/s10336-015-1177-6

Ghilain, A., and M. Bélisle. 2008. Breeding success of the Tree Swallows along a gradient of agricultural intensification. Ecological Applications 18:1140-1154. https://doi.org/10.1890/07-1107.1

Goldshtein, A., S. Markman, Y. Leshem, M. Puchinsky, and M. Charter. 2018. Nest-site interference competition with House Sparrows affects breeding success and parental care in Great Tits. Journal of Ornithology 159:667-673. https://doi.org/10.1007/ s10336-018-1541-4

Gowaty, P. A. 1984. House sparrows kill Eastern Bluebirds. Journal of Field Ornithology 55:378-380.

Grarock, K., D. B. Lindemayer, J. T. Wood, and C. R. Tidemann. 2013. Does human-induced habitat modification influence the impact of introduced species? A case study on cavity-nesting by the introduced Common Myna (Acridotheres tristis) and two Australian native parrots. Environmental Management 52:958-970. https://doi.org/10.1007/s00267-013-0088-7

Grarock, K., C. R. Tidemann, J. T. Wood, and D. B. Lindemayer. 2014. Understanding basic species population dynamics for effective control: a case study on community-led culling of the Common Myna (Acridotheres tristis). Biological Invasions 16:1427-1440. https://doi.org/10.1007/s10530-013-0580-2

Hindman, L. J., W. F. Harvey, and L. E. Conley. 2014. Spraying corn oil on Mute Swan Cygnus olor eggs to prevent hatching. Wildfowl 64:186-196.

Humane Society of the United States. 2009. Canada Goose egg addling protocol. The Humane Society of the United States, Washington, D.C., USA. [online] URL: https://www. humanesociety.org/sites/default/files/docs/wild-good-egg-protocol. pdf 
International Union for Conservation of Nature (IUCN). 2010. Biological invasions: a growing threat to biodiversity, human health and food security. IUCN Policy Brief. IUCN, Gland, Switzerland.

Kelly, D., C. Brindle, J. J. Ladley, A. W. Robertson, F. W. Maddigan, J. Butler, T. Ward-Smith, D. J. Murphy, and L. A. Sessions. 2005. Can stoat (Mustela erminea) trapping increase Bellbird (Anthornis melanura) populations and benefit mistletoe (Peraxilla tetrapetala) pollination? New Zealand Journal of Ecology 29:69-82.

Khan, H. A., S. Ahmad, M. Javed, K. Ahmad, and M. Ishaque. 2011. Comparative effectiveness of some mechanical repellents for management of Rose-ringed Parakeet (Psittacula krameri) in citrus, guava and mango orchards. International Journal of Agriculture and Biology 13:396-400.

Kibler, L. F. 1969. The establishment and maintenance of a bluebird nest-box project: a review and commentary. BirdBanding 40:114-129. https://doi.org/10.2307/4511555

Kumschick, S., and W. Nentwig. 2010. Some alien birds have as severe an impact as the most effectual alien mammals in Europe. Biological Conservation 143:2757-2762. https://doi.org/10.1016/j. biocon.2010.07.023

Larson, L. R., C. B. Cooper, and M. E. Hauber. 2016. Emotions as drivers of wildlife stewardship behavior: examining citizen science nest monitors' responses to invasive house sparrows. Human Dimensions of Wildlife 21:18-33. https://doi.

org/10.1080/10871209.2015.1086933

Lepczyk, C. A., A. G. Mertig, and J. Liu. 2004. Assessing landowner activities related to birds across rural-to-urban landscapes. Environmental Management 33:110-125. https://doi. org/10.1007/s00267-003-0036-Z

Linz, G. M., H. J. Homan, S. M. Gaukler, L. B. Penry, and W. J. Bleier. 2007. European Starlings: a review of an invasive species with far-reaching impacts. Pages 378-386 in G. W. Witmer, W. C. Pitt, and K. A. Fagerstone, editors. Managing vertebrate invasive species. USDA National Wildlife Research Center, Fort Collins, Colorado, USA.

Loss, S. R., T. Will, and P. P. Marra. 2013. The impact of freeranging domestic cats on wildlife of the United States. Nature Communications 4:1396. https://doi.org/10.1038/ncomms 2380

Loss, S. R., T. Will, and P. P. Marra. 2015. Direct mortality of birds from anthropogenic causes. Annual Review of Ecology, Evolution and Systematics 46:99-120. https://doi.org/10.1146/ annurev-ecolsys-112414-054133

Lowe, S., M. Browne, S. Boudjelas, and M. De Poorter. 2000. 100 of the world's worst invasive alien species. A selection from the global invasive species database. Aliens 12.

Manchester, S. J., and J. M. Bullock. 2000. The impacts of nonnative species on UK biodiversity and the effectiveness of control. Journal of Applied Ecology 37:845-864. https://doi.org/10.1046/ j.1365-2664.2000.00538.x

Martin, J. M., K. French, and R. E. Major. 2007. The pest status of Australian White Ibis (Threskiornis molucca) in urban situations and the effectiveness of egg-oil in reproductive control. Wildlife Research 34:319-324. https://doi.org/10.1071/WR07005
Moller, H., and N. Alterio. 1999. Home range and spatial organisation of stoats (Mustela erminea), ferrets (Mustela furo) and feral house cats (Felis catus) on coastal grasslands, Otago Peninsula, New Zealand: implications for Yellow-eyed Penguin (Megadyptes antipodes) conservation. New Zealand Journal of Zoology 26:165-174. https://doi.org/10.1080/03014223.1999.9518186

Nebel, S., A. Mills, J. D. McCracken, and P. D. Taylor. 2010. Declines of aerial insectivores in North America follow a geographic gradient. Avian Conservation and Ecology 5(2):1. https://doi.org/10.5751/ACE-00391-050201

Nentwig, W., E. Kühnel, and S. Bacher. 2010. A generic impactscoring system applied to alien mammals in Europe. Conservation Biology 24:302-311. https://doi.org/10.1111/j.1523-1739.2009.01289. $\mathrm{x}$

Orchan, Y., F. Chiron, A. Shwartz, and S. Kark. 2013. The complex interaction network among multiple invasive bird species in a cavity-nesting community. Biological Invasions 15:429-445. https://doi.org/10.1007/s10530-012-0298-6

Perry, G., H. Curzer, M. Farmer, M. L. Gore, and D. Simberloff. 2019. Historical, ethical, and (extra)legal perspectives on culpability in accidental species introductions. BioScience biz121:1-11. https://doi.org/10.1093/biosci/biz121

Phillips, T., and J. Dickinson. 2009. Tracking the nesting success of North America's breeding birds through public participation in Nestwatch. Pages 633-640 in T. D. Rich, C. Arizmendi, D. W. Demarest, and C. Thompson, editors. Proceedings of the Fourth International Partners in Flight Conference: tundra to tropics. Partners in Flight.

Pochop, P. A., J. L. Cummings, J. E. Steuber, and C. A. Yoder. 1998a. Effectiveness of several oils to reduce hatchability of chicken eggs. Journal of Wildlife Management 62:395-398. https:// doi.org/10.2307/3802304

Pochop, P. A., J. L. Cummings, C. A. Yoder, and J. E. Steuber. 1998b. Comparison of white mineral oil and corn oil to reduce hatchability in Ring-billed Gull eggs. Pages 411-413 in R. Barker and C. Crabb, editors. Proceedings of the Eighteenth Vertebrate Pest Conference. Costa Mesa, California, USA. https://doi. org/10.5070/v418110097

Radunzel, L. A., D. M. Muschitz, V. M. Bauldry, and P. Arcese. 1997. A long-term study of the breeding success of Eastern Bluebirds by year and cavity type. Journal of Field Ornithology 68:7-18.

Raleigh, D., J. D. Ray, B. A. Grisham, J. Siegrist, and D. U. Greene. 2019. Nest survival data confirm managed housing is an important component to the conservation of the Eastern Purple Martin. Wildlife Society Bulletin 43:93-101. https://doi. org/10.1002/wsb.941

Ratcliffe, N., I. Mitchell, K. Varnham, N. Verboven, and P. Higson. 2009. How to prioritize rat management for the benefit of petrels: a case study of the UK, Channel Islands and Isle of Man. Ibis 151:699-708. https://doi.org/10.1111/j.1474-919X.2009.00949. $\mathrm{X}$

Rosenberg, K. V., A. M. Dokter, P. J. Blancher, J. R. Sauer, A. C. Smith, P. A. Smith, J. C. Stanton, A. Panjabi, L. Helft, M. Parr, 
and P. P. Marra. 2019. Decline of the North American avifauna. Science 366:120-124. https://doi.org/10.1126/science.aaw1313

SAS Institute. 2012. SAS Statistical Software, version 9.4. SAS Institute, Cary, North Carolina, USA.

Scriven, D. H. 1993. Bluebird trails: a guide to success. Bluebird Recovery Committee of the Audubon Chapter of Minneapolis, Minneapolis, Minnesota, USA.

Soh, M. C. K., N. S. Sodhi, R. K. H. Seoh, and B. W. Brook. 2002. Nest site selection of the House Crow (Corvus splendens), an urban invasive bird species in Singapore and implications for its management. Landscape and Urban Planning 59:217-226. https:// doi.org/10.1016/S0169-2046(02)00047-6

Sparrow Swap. 2019. Sparrow Swap: a citizen science project. [online] URL: https://sparrowswap.org/

Stone, C. P., and L. L. Loope. 1987. Reducing negative effects of introduced animals on native biotas in Hawaii: what is being done, what needs doing, and the role of national parks. Environmental Conservation 14:245-258. https://doi.org/10.1017/S0376892900016453

Strubbe, D., and E. Matthysen. 2007. Invasive Ring-necked Parakeets Psittacula krameri in Belgium: habitat selection and impact on native birds. Ecography 30:578-588. https://doi. org/10.1111/j.0906-7590.2007.05096.x

Strubbe, D., and E. Matthysen. 2009. Experimental evidence for nest-site competition between invasive Ring-necked Parakeets (Psittacula krameri) and native Nuthatches (Sitta europaea). Biological Conservation 142:1588-1594. https://doi.org/10.1016/j. biocon.2009.02.026

Szabo, J. K., N. Khwaja, S. T. Garnett, and S. H. M. Butchart. 2012. Global patterns and drivers of avian extinctions at the species and subspecies level. PLoS ONE 7:e47080. https://doi. org/10.1371/journal.pone.0047080

Thibault, J.-C., J.-L. Martin, A. Penloup, and J.-Y. Meyer. 2002. Understanding the decline and extinction of monarchs (Aves) in Polynesian Islands. Biological Conservation 108:161-174. https:// doi.org/10.1016/S0006-3207(02)00102-7

Thomas, G. J. 1972. A review of gull damage and management methods at nature reserves. Biological Conservation 4:117-127. https://doi.org/10.1016/0006-3207(72)90012-2

Tillman, E. A., A. C. Genchi, J. R. Lindsay, J. R. Newman, and M. L. Avery. 2004. Evaluation of trapping to reduce monk parakeet populations at electric utility facilities. USDA National Wildlife Research Center - Staff Publications 391:126-129.

Tracey, J. P., B. S. Lukins, and C. Haselden. 2008. Hybridisation between Mallard (Anas platyrhynchos) and Grey Duck ( $A$. superciliosa) on Lord Howe Island and management options. Notornis 55:1-7.
U.S. Department of the Interior, U.S. Fish and Wildlife Service, U.S. Department of Commerce, and U.S. Census Bureau. 2013. 2011 National survey of fishing, hunting, and wildlife-associated recreation. U.S. Department of the Interior, U.S. Fish and Wildlife Service, U.S. Department of Commerce, and U.S. Census Bureau, Washington, D.C., USA. https://doi.org/10.3886/icpsr34699.v1

Weitzel, N. H. 1988. Nest-site competition between the European Starling and native breeding birds in northwestern Nevada. Condor 90:515-517. https://doi.org/10.2307/1368590

West, R. R. 1968. Reduction of a winter starling population by baiting its preroosting areas. Journal of Wildlife Management 32:637-640. https://doi.org/10.2307/3798951

Woinarski, J. C. Z., B. P. Murphy, S. M. Legge, S. T. Garnett, M. J. Lawes, S. Comer, C. R. Dickman, T. S. Doherty, G. Edwards, A. Nankivell, D. Paton, R. Palmer, and L. A. Woolley. 2017. How many birds are killed by cats in Australia? Biological Conservation 214:76-87. https://doi.org/10.1016/j.biocon.2017.08.006
Editor-in-Chief: Alexander L.Bond Subject Editor: Auriel M.V.Fournier
Sponsored by the Society of Canadian Ornithologists an Bird Studies Canada Parrainée par la Société des ornithologistes $d u$ Canada et Études d'oiseaux Canada

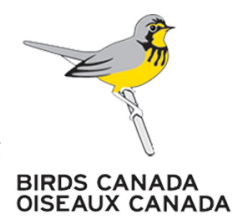

